\title{
An Analysis of the Transformation of Mega-Pharma's Business Model toward the Emerging Market
}

\author{
Yaeko Mitsumori ${ }^{a^{*}}$ \\ ${ }^{a}$ Osaka University, 1-1 Yamadaoka, Suita, Osaka 565-0871, Japan
}

\begin{abstract}
The Trade-Related Aspects of Intellectual Property Rights (TRIPS) requires all member countries of the World Trade Organization (WTO) to introduce a TRIPS-compatible patent law into their countries. Due to the enforcement of TRIPS in 1995, India in 2005 revised its patent law and enacted the Patents (Amendment) Act, 2005. The 2005 ACT included product patent in pharmaceutical field. Due to the new patent law with product patent protection, large foreign capital pharmaceutical companies one after another re-entered the Indian market and started engaging in both R\&D and production targeting the Indian market. However recent data shows the number of patent applications has been declining over the past several years and the number of patented drugs launched in India did not increase so rapidly. This study analyzes transitions of business models of foreign pharmaceutical companies in India based on the patent application data, and the trend of patented drugs in the market. A data analysis and a series of interviews with stakeholders were conducted. As a result of both a quantitative and a qualitative analysis, it was found that foreign pharmaceutical companies changed their strategies in the Indian pharmaceutical market. Since India was required to introduce product patents in the pharmaceutical area, there have been many arguments that once India introduces a product patent, the Indian pharmaceutical industry may decline due to the rapid introduction of foreign pharmaceutical products in the country; many academic papers were published in this context during that time. However, since 2005, when product patents were actually introduced in India, few academic papers were published. This study is unique as it discusses the effects of the introduction of product patents on the Indian pharmaceutical market.
\end{abstract}

Keywords:

Intellectual Property; WTO/TRIPS;

Developing Countries; Newly Developing Countries; Pharmaceuticals;

Ever Greening.

Article History:

$\begin{array}{llll}\text { Received: } & 11 & \text { May } & 2020 \\ \text { Accepted: } & 09 & \text { July } & 2020 \\ \text { Published: } & 01 & \text { August } & 2020\end{array}$

\section{1- Introduction}

As a result of the implementation of the World Trade Organization (WTO)'s Trade-Related Aspects of Intellectual Property Rights (TRIPS), which took effect in 1995, all members of the WTO, including advanced countries and developing countries, are required to introduce TRIPS-compatible patent law, including product patents, in their countries. India, a member of WTO, introduced product patent in 2005 in pharmaceutical field. Once India was required to re-introduce product patent, very large pharmaceutical companies so-called Mega pharma companies one after another re-entered the Indian market targeting the country with the world second largest population. These Mega pharma companies applied patents to IPO and started engaging in R\&D and manufacturing their patented products. However, the number of patent applications in the field of pharmaceuticals has been declining over the past several years and the number of patented drugs in Indian market has not significantly increased in India since 2005. This study analyzed Mega pharma companies' strategies toward India - one of the phar-merging countries and No. 3 pharmaceutical country in the world on volume - based on IPR data and marketing data.

\footnotetext{
* CONTACT: Dt4y-mtmr@asahi-net.or.jp DOI: http://dx.doi.org/10.28991/esj-2020-01228
}

(C) 2020 by the authors. Licensee ESJ, Italy. This is an open access article under the terms and conditions of the Creative Commons Attribution (CC-BY) license (https://creativecommons.org/licenses/by/4.0/). 
As mentioned above, many papers were published at the end of the 1990s and early 2000s, before product patents were introduced in India; however, few academic papers were published after product patents were introduced in 2005. This study, which analyzes the effects of the introduction of product patents in India, is considered significant.

This article consists of 10 chapters: Chapter 1 is an introduction and Chapter 2 is the literature review. Chapter 3 describes India's current economic status. Chapter 4 explains the pharmaceutical industry in India. Chapter 5 describes intellectual property rights in India. Chapter 6 presents the strategies of Mega-pharma in India. Chapter 7 introduces two landmark incidents in India while Chapter 8 provides a discussion of the results. Chapter 9 presents the conclusion and Chapter 10 lists some limitations of this study.

\section{2- Literature Review}

As mentioned above, there is not so many academic literature directly related to this article. Under the Patents Act, 1970 (1972-2005), which did not have any product patent protection, the Indian pharmaceutical industry developed rapidly. Many Indian pharmaceutical products with low price and high quality were used in the Third World. Under the circumstances India was required to introduce product patents because of TRIPS. Once India was required to introduce product patents, many stake holders including Indian people, Indian pharmaceutical industry and international NGO/NPOs that send Indian drugs to the Third World, argued once a product patent is introduced in India, Indian pharmaceutical industry might decline because foreign capital pharmaceutical products would rapidly enter the Indian market and might occupy it. Those days, many academic papers which either predicted the future status of the Indian pharmaceutical industry or discussed pro or con of an introduction of product patent in India were written. However, not so many academic papers were written since an introduction of product patent sin India in 2005.

Differding analyzed new chemical entity (NCE) development efforts by Indian pharmaceutical companies [1]. According to a study by Differding, a total of 168 molecules were developed by Indian pharmaceutical companies between 1996 and 2016. However only one NCE has so far been launched in India. The Indian pharmaceutical companies have either exited or halted new drug discovery, and only nine companies have been actively engaged in new drug discovery today. Based on his own research, Differding found contributions to the growing pipelines has been shifting from the established pharmaceutical companies to research intensive biotechnology companies. He also found current projects are targeting increasingly best-in-class compounds rather than first-in-class drugs [1].

Gapakumar G Nair, et al, selected several so-called "Landmark" patent litigation cases in India and analyzed the development and court decisions of these cases [2]. Since litigations take a long time, many of these cases are still in the court process. However foreign capital companies which most of the cases hold product patens for NCEs won an injunctive relief in some infringement suits. Gapakumar G Nair, et al, also noticed that there have been mixed reactions from developed and developing countries \& NGOs with regard to the world-class judgment from the Supreme Court of India and Controller General of Patents, Designs \& Trade Marks of India [2].

People in developed countries tend to consider IPR was not enforced correctly in India especially since Supreme Court of India's decision against Novartis' Gleevec case. Senior Advocate of Delhi High Court Prathiba M. Singh analyzed IP related litigation cases in India between 1995 and 2014 [3]. She found among the 2,157 cases which a high court granted a decision, IP holders won in 1,433 cases $(66.4 \%)$, while the IP holders lost in the rest 724 cases. She also found that among the 2,157 cases, foreign capital firms were engaged in 595 cases. Among the 595 cases, foreign capital firms won in 387 cases (65\%). Summing up her own analyses, Ms. Singh concluded that IP holders won in nearly two third of the IP related litigation cases in India [3].

Horner analyzed Indian pharmaceutical firm's business after a product patent was introduce in India [4]. When India was decided to introduce product patent in pharmaceutical field, many people including the citizens groups and NGO/NPO, argued once product patents are introduced, Indian domestic industry would decline because foreign capital company's products might rapidly enter the Indian market. However, it did not happen by now. Large Indian pharmaceutical companies have continued to grow. Horner found large Indian pharmaceutical companies shifted their target from developing markets to developed markets and are engaged in more formal technology transfer as part of collaborative relationship with foreign capital companies. Based on his own study Horner found Indian pharmaceutical industry's adaptation rely on broader institutional setting [4].

Dhar and Joseph analyzed how Indian pharmaceutical companies responded to the challenges posed by TRIPS consistent patent regime by using several parameters. Based on their parameter analysis, they found that major Indian pharmaceutical companies did not have structural weaknesses at the moment, and these firms have been keeping significant capital investment and maintained the size of operation. They also found these Indian pharmaceutical firms have been pouring significant amount of capital into R\&D and actively applying for patents [5]. 


\section{3- The Current Economic Status of India}

\section{3-1- Indian Economic Development}

India has achieved rapid economic development, and according to JETRO, India achieved 7.0\% GDP growth in 2018 [6]. The United Nation's World Economic Situation and Prospect mentioned the Indian economy expanded by $7.2 \%$ in 2018 and the report projected Indian economy would expand at 7\% in 2019 and 7.1\% in 2020 [7]. OECD Economic Outlook Projection said India achieved an economic growth of $7.0 \%$ in 2018 is expected to grow at $7.2 \%$ in 2019 and at $7.4 \%$ in 2020 [8].

Table 1. India's Economic Indicators.

\begin{tabular}{lccc}
\hline Items & $\mathbf{2 0 1 6}$ & $\mathbf{2 0 1 7}$ & $\mathbf{2 0 1 8}$ \\
\hline Real GDP Growth Rate & $7.1 \%$ & $6.7 \%$ & $7.0 \%$ \\
Nominal GPD & 121.960 (1 bil. INR) & 130.108 (1 bil. INR) & n.a. \\
Per Capita Nominal GPD & 1.749 (USD) & 1.983 (USD) & 2.036 (USD) \\
Industrial Production & $4.6 \%$ & $4.3 \%$ & n.a. \\
Consumer Price Index & $4.5 \%$ & $3.6 \%$ & n.a. \\
\hline
\end{tabular}

Source: India's Economic Indicators by JETRO

\section{4- Pharmaceutical Industry in India}

\section{4-1- History}

When India won independence in 1947 from the Great Britain, there was no pharmaceutical industry in India. That's one of the reasons why the Indian pharmaceutical market was dominated by large foreign capital companies, so-called Mega Pharma companies in 1950s and 1960s [9]. Started in 1970s, Indian domestic pharmaceutical industry achieved rapid growth because Indian patent law then (The Patent Act, 1970) did not have any product patent protection for medicines [10].

Table 2. Indian Pharmaceutical Market [9].

\begin{tabular}{ccccccc}
\hline & $\mathbf{1 9 5 0 - 5 1}$ & $\mathbf{1 9 6 0 - 6 1}$ & $\mathbf{1 9 7 0 - 7 1}$ & $\mathbf{1 9 8 0 - 8 1}$ & $\mathbf{1 9 9 0 - 9 1}$ & $\mathbf{2 0 0 0 - 2 0 0 1}$ \\
\hline Manufactures (No) & 200 & & 2300 & 6400 & 16000 & 20000 \\
Investment (Rs. Mil) & 50 & 560 & 2250 & 6000 & 9500 & 30000 \\
R\&D Expenditure (Rs. Mil) & - & - & 100 & 290 & 800 & 4000 \\
Production (Rs. Mil) & 100 & 1130 & 4000 & 14400 & 45700 & 228870 \\
Exports (Rs. Mil) & - & 16 & 85 & 463 & 7848 & 87290 \\
Imports (Rs. Mil) & - & 176 & 243 & 968 & 4075 & 29800 \\
\hline
\end{tabular}

From 1970 s to 1980 s, the entry barrier to the Indian pharmaceutical industry was very low so that many companies rushed to enter the Indian pharmaceutical market. As a result, prices for pharmaceutical products became very low in India [11].

India has a long history of study of chemistry and chemistry research was one of the strengths of India. That was one of the reasons why India was able to produce qualified pharmaceutical products. With the very low prices and high quality, Indian pharmaceutical products were selling very well and Indian pharmaceutical industry has grown so rapidly [12].

\section{4-2- Current Market in India}

According to IBEF, India Brand Equity Foundation, the current Indian Pharmaceutical sector was valued at $\$ 33$ bil. IBEF expected that the sector would reach $\$ 50$ bil. by 2025 [13]. According to IBEF, the Indian pharmaceutical industry has many strong points:

- Cost advantage;

- Skilled manpower;

- National Health Policy 2015 of India;

- Reduction of approval time for new facilities;

Increasing penetration of health insurance $[13,14]$. 
Today Indian pharmaceutical industry is No. 3 on volume in the world and No. 11 on value in the world. IQVIA, an information services company specialized in medical industry, predicted Indian pharmaceutical industry would be No. 9 in the world by 2023 [15].

\section{4-3- Exports and Import}

One of the features of Indian pharmaceutical industry is it is an export-oriented industry. Pharmaceutical exports from India which include bulk drugs, intermediates, drug formulations, biologicals Ayush \& herbal products and surgicals reached US \$17.28 bil. in FY18 and US\$19.14 bil. in FY19 [13].

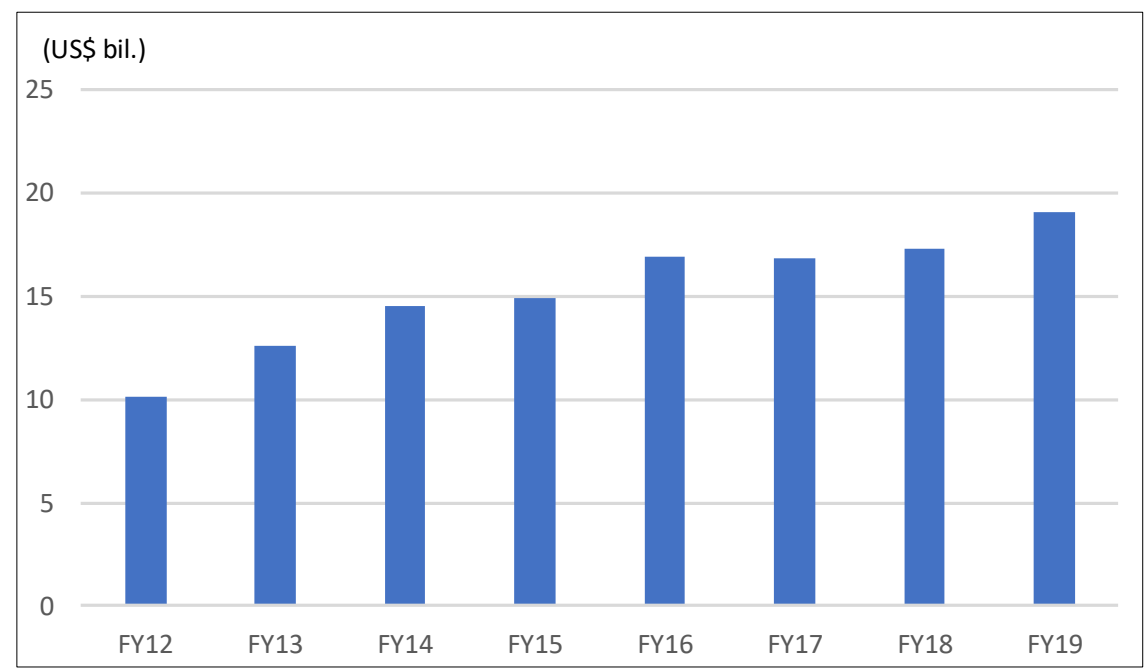

Figure 1. Pharmaceutical Exports from India (IBEF Pharmaceuticals 2019 [13]).

The biggest export destination for Indian pharmaceutical products is the U.S. In FY2018, 31\% of India's pharmaceutical exports went to the North America, followed by $19.4 \%$ to Africa and $15.9 \%$ to EU [13].

\section{4-4- Market by Classification}

In the Indian pharmaceutical sector, generic drugs occupy the largest share of $70 \%$ which is followed by Over-theCounter (OTC), 21\%, and patented drugs, 9\% [13].

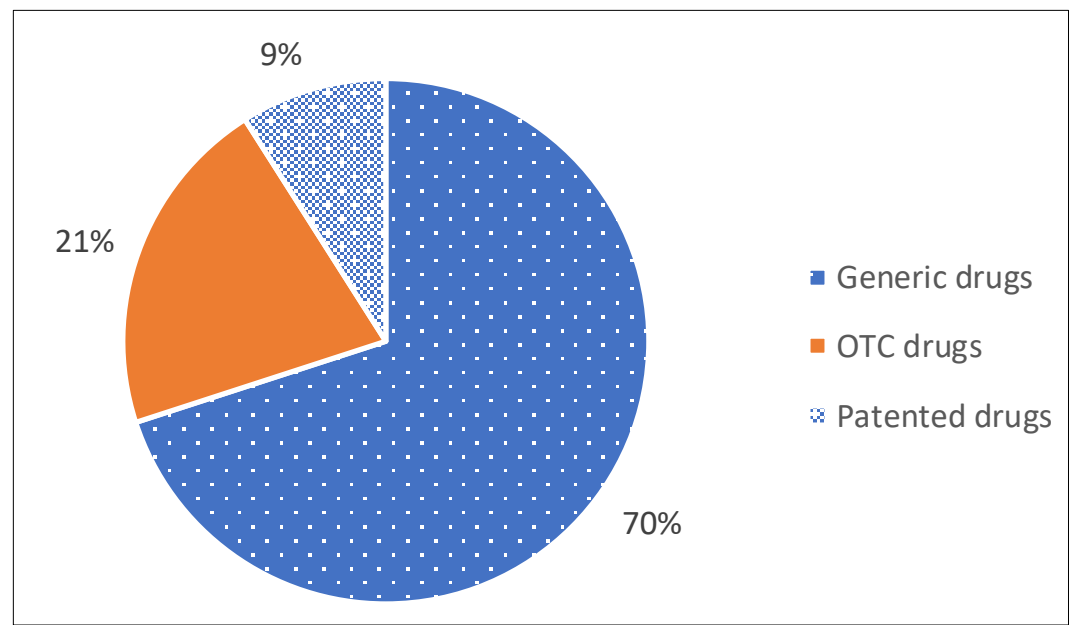

Figure 2. Indian Pharmaceutical Market by Segment (IBEF Pharmaceuticals 2019 [13]).

\section{4-5- Pharmaceutical Market by Indication}

India is a developing country. When pharmaceutical products were classified by disease, so-called acute disease drugs occupy large shares. However recently so-called lifestyle diseases such as diabetes have been prevalent in India. As of 2018, anti-infectives drugs, cardiac disease drugs and gastro intestinal disease drugs are the top three segments in India. 


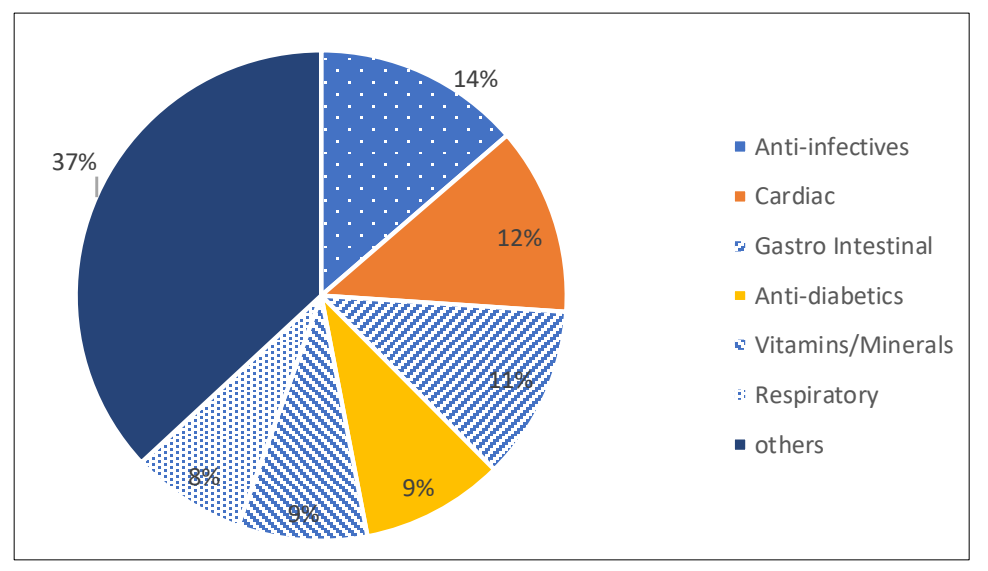

Figure 3. Pharmaceutical Market by Indication (IBEF Pharmaceuticals 2019 [13]).

\section{5- IPR in India}

\section{5-1- Patent System in India}

India has a long history of patent protection. In 1911, when India was a colony of Great Britain, the Indian Patents and Designs Act, 1911 was enacted. The Indian Patents and Designs Act, 1911 had both process and product patent protection in pharmaceutical field $[16,17]$.

\section{5-2- Transition of Patent Law}

When India won independence from Great Britain, there was no pharmaceutical industry in India [9]. That's why the Indian market was dominated by foreign capital companies so-called Mega Pharma. Indira Priyadarshini Gandhi, then the prime minister of India, disliked to see the Indian pharmaceutical market was occupied by foreign capital companies. She scrapped the 1911 patent law and compiled a new patent act, Indian Patents Act, 1970. The Patents Act, 1970 did not have any product patent protection in the field of medicine $[10,18]$.

Under the India Patents Act, 1970, India pharmaceutical industry has been flourishing [11]. However, due to TRIPS, India was required to introduce product patent by 2005 [19]. In 2005 India introduced Patents (Amended) Act, 2005. Indian Patents (Amended) Act, 2005 protects both process and product patent in the field of pharmaceuticals [20].

\section{5-3- Patent Application and Granted}

The Indian Patent Office (IPO) is administered by the Office of the Controller General of Patents, Designs \& Trade Marks. There are four patent offices: Delhi, Mumbai, Chennai and Kolkata. IPO each year compiles and releases Annual Report which carry all data of IPRs [21, 22]. Figure 4 shows numbers of patent applied, examined and granted between 2002/2003 - 2016/2017 [23]. Although there are fluctuations, the number of patent applications in India has increased since 2002/2003.

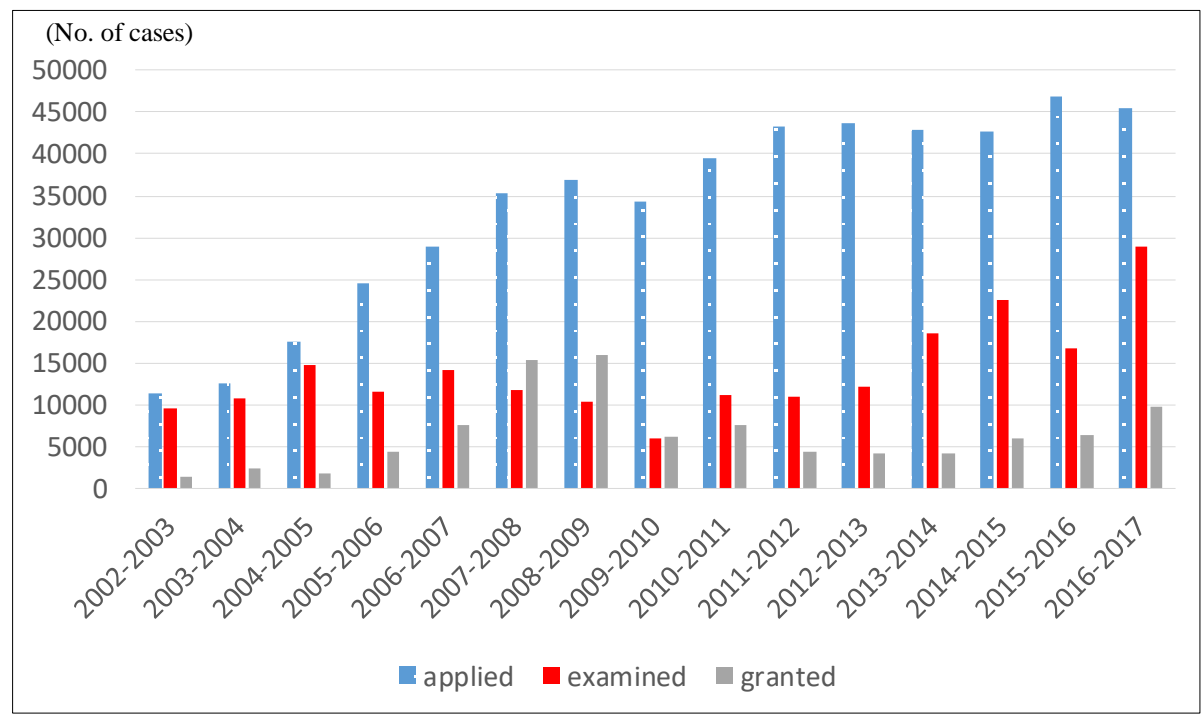

Figure 4. Patent Applied, Examined and Granted in India 2002/03-2016/17; (IPO Annual Reports 2002/20032016/2017 [23]). 


\section{6- Strategies of Mega-pharma toward India}

Table 3 shows top 10 pharmaceutical companies in the world [23, 24].

Table 3. Top 10 pharmaceutical companies in the world.

\begin{tabular}{lcc}
\hline & & Sales Reveneus (US \$ Bil.) \\
\hline 1 & P fizer & 46.1 \\
2 & Novartis & 43.0 \\
3 & Roche & 41.9 \\
4 & Sanofi & 39.6 \\
5 & Johnson \& Johnson & 36.3 \\
6 & Merck & 35.4 \\
7 & GSK & 28.9 \\
8 & AbbVie & 28.2 \\
9 & Gilead Sciences & 25.7 \\
10 & Amgen & 21.8 \\
\hline
\end{tabular}

*Source: Nikkei Bio Yearbook 2019

In the field of pharmaceutical industry, very large pharmaceutical companies are called Mega-Pharma. These Mega-pharma companies one after another re-entered the Indian pharmaceutical market once India was decided to reintroduce a product patent in the field of pharmaceuticals. Some companies set up their own R\&D centers while other companies set up their offices in major cities of India such as New Delhi, Mumbai or Hyderabad [24, 25]. Under the Patents (Amendment) Act, 1999, the Indian Government started accepting product patent applications in 1995 and under the Patents (Amendment) Act, 2005 the Indian government started examining these applications [26]. Once mailbox was set up, Mega-pharma companies started applying their patents to IPO. Figure 5 shows the number of patent application in the field of pharmaceutical products in India [27].

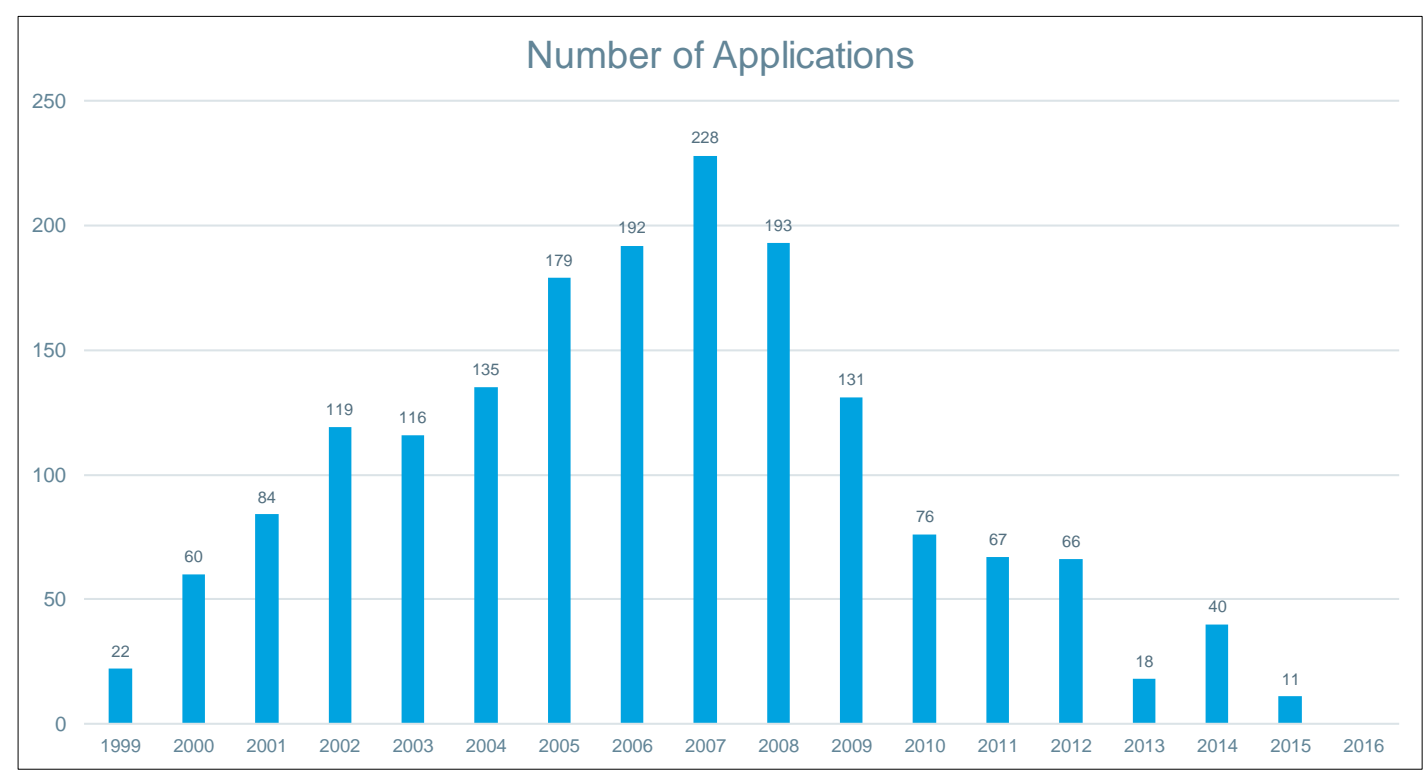

Figure 5. Number of Patent Application 1999 - 2015, IQVIA 2017 [27].

As mentioned above, the Indian patent office set up a mailbox based on the Patents (Amendment) Act 1999 and started accepting product patent applications. The Indian patent office started examining product patents in 2005 based on the Patents (Amendment) Act, 2005. The number of patent applications has increased since 1999 and reached 228 in 2007; however, since then, the number has declined.

According to IQVIA, almost all of the patent applications for these pharmaceutical products were submitted by foreign capital companies including Mega-pharma.

\section{7- Two Landmark Incidents in India}

\section{7-1- Section 3(d)}

India in 2005 revised its patent law and introduced product patent protection. However, the Indian Patents 
(Amendment) Act, 2005 includes a special safe-guard article called Section 3(d). Section 3(d) is shown below:

"(d) the mere discovery of a new form of a known substance which does not result in the enhancement of the known efficacy of that substance or the mere discovery of any new property or new use for a known substance or of the mere use of a known process, machine or apparatus unless such known process results in a new product or employs at least one new reactant.

Explanation-For the purposes of this clause, salts, esters, ethers, polymorphs, metabolites, pure form, particle size, isomers, mixtures of isomers, complexes, combinations and other derivatives of known substance shall be considered to be the same substance, unless they differ significantly in properties with regard to efficacy".

Based on the Section 3(d), the Indian patent office and courts have rejected "major" patents whose patentability had been approved in many other countries.

There were two remarkable events regarding the Section 3(d) occurred in India: the first one was Swiss Pharmaceutical company Novartis' Gleevec Law Suit, and the other one was India's first compulsory license issuance against German Pharmaceutical company Bayer's Nexavar.

\section{7-2- Novartis’ Gleevec Law Suit}

Novartis submitted patent application for Gleevec (general name: Imatinib), one of the most common anti-cancer drugs, via mailbox set up by Indian Patent Office. The Indian Patent Office, however, in 2006 rejected Gleevec patent based on Section 3(d). Novartis unsatisfied to the rejection, brought the case to a court. However, both High Court of Madras and the Intellectual Property Appellate Board (IPAB) dismissed Novartis' claims. The litigation was brought to the Supreme Court of India. In April 2013 the Indian Supreme Court dismissed Novartis' patent application based on Section 3(d) [28-30].

\section{7-3- India's First Compulsory License Issuance}

The Controller General of Patents Designs and Trade Marks of India in March 2012 granted Natco Pharma Limited, an Indian generic drug manufacturer, a compulsory license for Bayer AG's Nexavar (general name: sorafenib), an oncology drug. Due to the order, Natco was allowed to manufacture and sell a generic version of Nexavar (general name: sorafenib) but had to pay $6 \%$ royalty on the net sales to Bayer. In addition, Natco was able to charge Rs 8,800 for a monthly dose (for 120 tablets) of the drug.

Since the India's very first compulsory license issuance, there is no other compulsory license has been issued in India [31].

\section{7-4- Impact of These Two Landmark Incidents}

Repercussions to these two incidents were widely divided.

Regarding the Supreme Court ruling against Novartis, Médecins Sans Frontières (MSF), an international NGO working for access to medicine in the Third World, released a press release on April 12013 mentioning, "This is a huge relief for the millions of patients and doctors in developing countries who depend on affordable medicines from India" [32].

On the other hand, Ranjit Shahani, vice president of Novartis India mentioned, "Companies like Novartis would invest less money in research in India as a result of the ruling" [33].

Chip Davis, the executive vice president of advocacy at the Pharmaceutical Research and Manufacturers of America mentioned, "It is another example of what I would characterize as a deteriorating innovation environment in India." Meanwhile, Anand Grover, a lawyer working for Cancer Patients Aid Association in India, said, "The ruling confirmed that India has a very high bar for approving patents on medicines" [33].

\section{8- Discussion}

Due to TRIPS, India in 2005 revised its patent law and introduced product patent protection. The new Indian law, Patents (Amendment) Act, 2005 was supposed to be an international TRIPS compatible patent law. However, Patents (Amendment) Act, 2005 contains a unique safe-guard article, called Section 3(d). Based on Section 3(d), the Indian government and Indian courts rejected internationally recognized patents such as Gleevec patent.

Once India was decided to re-introduce product patent protection, Mega pharma companies re-entered the Indian market. These Mega pharma companies started applying product patents to IPO.

That's one of the reasons why the number of pharmaceutical patent application in India rapidly increased since late 
1990s. The number reached 228 in 2007; however, since then the number rapidly declined.

The trend suggests these Mega pharma companies changed their strategies for Indian pharmaceutical market.

As described above, there were two landmark incidents occurred in 2012 and 2013 in India. One of them was Supreme Court's decision on Novartis' Gleevec in 2013 and the other one was compulsory license issuance in 2012.

For Mega-pharma companies both incidents were huge blows. It is considered that through these incidents, these Mega pharma companies may have reviewed their strategies toward the Indian market. When these Mega pharma companies re-entered Indian market, they considered Indian market as one of the most prospective markets. However, through these two incidents they found IPR enforcement in India was quite weak and IPR was not fully protected in India, and thus eventually they decided not to apply patents to IPO.

Fujii (2018), head of IPR division of Japan Pharmaceutical Manufacturing Association (JPMA) said foreign capital companies became cautious toward Indian market [34]. "In around 2005 we looked for Indian market as a prospecting market," Fujii (2018) said. "However, several incidents occurred in India since then. Through these incidents we became to think we had better take a wait-to-see position at the moment toward Indian market," he added [34].

These foreign capital firms still may seek for several business opportunities in Indian market: they may find their contract manufacturing partners or contract research and development partners; out-licensing partners or voluntary licensing partners.

\section{9- Conclusion}

The pharmaceutical industry of India is the world No. 3 in volume and No. 9 in value. With high quality and cheap prices, Indian pharmaceutical products are popular not only in the Third World but also in advanced countries.

India revised its patent law in 2005 and introduced product patent protection in 2005. Taking advantage of the revision of the patent law in India in 2005, almost all of so-called Mega pharma companies re-entered the Indian market targeting the huge consumption market. These Mega pharma companies launched R\&D, manufacturing and marketing in Indian market. The number of patent applications by these Mega pharma companies rapidly increased between the late 1990s and mid-2000s in India.

However, two landmark incidents occurred in India - Supreme Court's decision on Gleevec patent in 2013 and compulsory license issuance in 2012. Through these events these Mega-pharma companies seem to have changed their business model in the Indian market. The number of patent applications significantly dropped since the mid-2000s. These foreign capital firms still may seek for several business opportunities in Indian market.

Finding contract manufacturing partners or conducting contract research may become one of their new directions.

Piramal Pharmaceuticals, a major pharmaceutical company in India, used to be an integrated drug company engaged in drug discovery, development, manufacturing, and marketing. However, in 2015, the firm changed its business model. Currently, it provides contract manufacturing and contract research services only for foreign capital companies. According to IBEF Pharmaceuticals, there are more than 1000 contract research and manufacturing service (CRAMS) companies in India and CRAMS business in India has reached a compound annual growth rate (CAGR) of $48 \%$.

\section{0- Limitations}

Due to changes in the circumstances surrounding the pharmaceutical industry, Mega-pharma firms began to pay more attention to issues of access to medicine in the global market. Some pharmaceutical companies declared they would not seek patent protection in least developed countries (LDCs) while some other pharmaceutical firms granted voluntary licenses to Indian pharmaceutical companies.

In 2016, GlaxoSmithKline (GSK), a Mega-pharma based in the United Kingdom, declared that the company would not seek patent protection in LDCs or low-income countries. India is actually not an LDC but a lower middle-income country (LMICs). GSK stated that the firm would still apply for patents in LMICs; however, it will grant a license to local pharmaceutical companies in LMICs, which will let local firms supply inexpensive generic drugs for 10 years.

In September 2014, Gilead Sciences, another Mega-pharma company in the United States, granted voluntary licenses for Type $\mathrm{C}$ hepatitis medication to 11 Indian companies, under which these Indian pharmaceutical companies can export their products to 104 designated developing countries.

These are new trends in the pharmaceutical industry. The author plans to follow these new trends when she studies the business models of Mega-pharma in the Indian market in the future. 


\section{1- Conflict of Interest}

The author declares that there is no conflict of interests regarding the publication of this manuscript. In addition, the ethical issues, including plagiarism, informed consent, misconduct, data fabrication and/or falsification, double publication and/or submission, and redundancies have been completely observed by the authors.

\section{2- References}

[1] Differding, Edmond. "The Drug Discovery and Development Industry in India-Two Decades of Proprietary Small-Molecule R\&D.” ChemMedChem 12, no. 11 (June 1, 2017): 786-818. doi:10.1002/cmdc.201700043.

[2] Nair, G. Gapakumar, et al. "Landmark Pharma Patent Jurisprudence in India,” Journal of Intellectual Property Rights, Vol. 19, March (2014): 79-88.

[3] Singh, M. Prathiba. "Breaking the Anti-IP Myth,” Managing Intellectual Property, (September 2014).

[4] Horner, Rory. "The impact of patents on innovation, technology transfer and health: A pre-and post-TRIPs analysis of India's pharmaceutical industry." New Political Economy 19, no. 3 (2014): 384-406. doi:10.1080/13563467.2013.796446.

[5] Dhar, Biswajit, and Reji K. Joseph. "The Challenges, Opportunities and Performance of the Indian Pharmaceutical Industry Post-TRIPS.” ARCIALA Series on Intellectual Assets and Law in Asia (September 2019): 299-323. doi:10.1007/978-981-138102-7_13.

[6] The Japan External Trade Organization (JETRO), Japan. Available online: https://www.jetro.go.jp/en/ (accesses on 24 May 2020).

[7] United Nations, Available online: https://www.un.org/en/ (accesses on 24 May 2020).

[8] OECD Economic Outlook Projection, 2020, Available online: http://www.oecd.org/economic-outlook/june-2020/ (accesses on 24 May 2020).

[9] Bhojwani, H. R. "Developing innovative capacity in India to meet health needs." Innovation In Developing Countries To Meet Health Needs (2005): 112.

[10] The Patent Act, India, 1970. Available online: http://www.ipindia.nic.in/writereaddata/Portal/IPOAct/1_31_1_patent-act-197011march2015.pdf (accesses on 24 May 2020).

[11] Minato, Kazuki. "Background of Indian Pharmaceutical Industry and changes after TRIPS Agreement," In Generic Medicine Market in Japan and Pharmaceutical Industry in India and China, edited by edited by Kubo, Kensuke, Japan, IDE-JETRO (2007): 21-54.

[12] Yaeko Mitsumori, "Study on the roles of the Section 3d of Indian Patent Act for lightening negative impact of product patent introduction in 2005 on Indian pharmaceutical industry," Technology and Economy, No. 526, Japan MOT Society, (December 2010): 50-57.

[13] IBEF Ppharmaceuticals May 2019, IBEF (2019). Available online: https://www.ibef.org/industry/indian-pharmaceuticalsindustry-analysis-presentation (accesses on 11 July 2020).

[14] Seyedimany, Arian. "Stock Price Reactions on NASDAQ Stock Exchange for Special Dividend Announcements." Emerging Science Journal 3, no. 6 (December 1, 2019): 382-388. doi:10.28991/esj-2019-01200.

[15] The Global Use of Medicine in 2019 and Outlook to 2023 Institute Report, IQVIA, 2019. Available online: https://www.iqvia.com/-/media/iqvia/pdfs/institute-reports/the-global-use-of-medicine-in-2019-and-outlook-to-2023.pdf. (accesses on 29 January 2019).

[16] History of Indian Patent System, IPO, India, 2020. Available online: http://www.ipindia.nic.in/history-of-indian-patentsystem.htm. (accesses on 18 April 2020).

[17] The Indian Patents and Designs Act, India, 1911. Available online: http://theindianlawyer.in/statutesnbareacts/acts/d42.html. (accesses on 23 April 2020).

[18] MITSUMORI, Yaeko, and Akio NAGAHIRA. "Qualitative \& Quantitative Analyses of Impact of a Safeguard Section of Indian Patent Law 2005." International Journal of Japan Association for Management Systems 8, no. 1 (2016): $39-46$. doi:10.14790/ijams.8.39.

[19] WTO. TRIPS, "Which countries are using the general transition periods? Frequently asked questions about TRIPS (traderelated aspects of intellectual property rights) in the WTO, 2020. doi:10.4337/9781781006047.00016. Available online: https://www.wto.org/english/tratop_e/trips_e/tripfq_e.htm\#Transition. (accesses on 11 April 2020).

[20] Patent (Amended) Act, 2005 The Patents (Amendment) Act, India, 2005. Available online: http://ipindia.nic.in/writereaddata/ Portal/IPOAct/1_69_1_patent_2005.pdf. (accesses on 23 May 2020). 
[21] The Indian Patent Office (IPO), India, 2020. Available online: http://www.ipindia.nic.in/ (accesses on 23 April 2020).

[22] India. Annual Report 2016-2017 Intellectual Property India, The Office Of The Controller General Of Patents, Designs, Trade Marks And Geographical Indications India, 2016. Available online: http://www.ipindia.nic.in/writereaddata/Portal /IPOAnnualReport/1_94_1_1_79_1_Annual_Report-2016-17_English.pdf. (accesses on 29 March 2020).

[23] IPO Annual Reports 2002/2003 - 2016/2017. India. Available online: https://www.sebi.gov.in/sebiweb/home/HomeAction. do?doListing=yes $\&$ sid $=4 \&$ ssid $=24 \&$ smid $=0$ (accesses on 05 April 2020).

[24] Nikkei Business Publication, Nikkei Bio Yearbook 2019, 2018. Available online: http://www.nikkeibp.com/adinfo/whatsnew/ (accesses on 05 April 2020).

[25] Mitsumori, Yaeko. "India's First Compulsory License: Its Impact on the Indian Pharmaceutical Market as well as the World Market,” In Proceedings of PICMET 2014, July 27-30, Ishikawa Japan, (2014): 1437-1443.

[26] Patents (Amendment) Act, 1999. India. Available online: http://www.ipindia.nic.in/writereaddata/Portal/IPOAct/1_34_1_ patents-amendment-act-1999.PDF.(accesses on 25 March 2020).

[27] IQVIA Patent Analysis- Brazil / India / Philippines by GMI Analyst Services (2017).

[28] India. In the High Court of Judicature at Madras Dated: 06.08.2007 Coramthee Hon'ble Mr. Justice R. Balasubramanian and The Hon’ble Mrs. Justice Prabha Sridevan W.P. Nos. 247559 and 24760 of 2006.

[29] Intellectual Property Appellate Board M.P. Nos 1 to 5/2007 in TA/1 to 5/2007/PT/CH and M.P.No.33/2008 IN TA/1/2007/PT/CH Friday This the 26th Day of June 2009, Indi, 2009.

[30] In the Supreme Court of India Civil Appellate Jurisdiction CIVIL Appeal Ns. 2706-2716 of 2013, India.

[31] Application for Compulsory License under Section 84(1) of the Patents Act, 1970 in Respect of Patent No. 215758, India, 1970.

[32] MSF, India: Supreme Court delivers historic verdict in Novartis case India, April 2013. Available online: https://www.msf.org/indian-supreme-court-delivers-verdict-novartis-case. (accesses on 11 March 2020).

[33] Harris, Gardiner and Thomas, Katie. "Low cost drugs in Poor Nations Get a Lift in Indian Court,” NYT April 2, 2013.

[34] Fujii, Mitsuo, head of IPR division of Japan Pharmaceutical Manufacturing Association (JPMA), Interviewed by Yaeko Mitsumori, December 2018. 